\title{
The Baby Networks: Nordic Positions Before the Internet
}

\author{
Tomas Ohlin \\ Formerly of Linköping University and Stockholm University \\ tomas@telo.se
}

\begin{abstract}
This paper discusses the computer network situation immediately before the arrival of the internet. In various countries, there were a number of isolated network "islands," following different standards of technical characteristics called videotex. The paper discusses the different regional standards that were used and what types of services were made available, and asks what role the Nordic countries played in this development and in the transition to the internet.
\end{abstract}

Keywords: CEPT-3, internet, Minitel, Prestel, standards, TCP/IP, TeleGuide, videotex, Viewdata.

\section{The International Background}

One does not have to be religious to be challenged about how it all started. All of a sudden, there were islands, and all of a sudden, island organizations started ferry lines of connection. The internet was born and, after a few years, there were so many users. Then, who defined the islands? Were there islands everywhere, even in the Nordic countries? Moreover, what language did they speak for connection?

There are several priests in this church. How did it start? Was it a big network bang-a concentrated point of supreme intelligence that simply blew up?

Some of us who were there refer to the story of a growth of small islands that enlarged intermittently. Surely, the course was not quite smooth. Many analysts stressed early ARPA computer connections and their technically formatted messages. Some refer to university computer connections that developed between academic computer science departments, while others point directly to early versions of TCP/IP and preach that only with this standard did it all become possible. Many of us applaud Tim Berners Lee, who received all his medals for defining the web grammar.

The technological pioneers were active in the 1960s. The DARPA collection of large - primarily military - computers became technologically connected at that time, becoming the ARPANET. The same period also already saw the development of the TCP/IP protocol. Pioneering connection experiments took place in several countries in the 1970s, and time-sharing also appeared on the market, building up local star networks around centralized computer stations.

Tim Berners-Lee and his scientific group published their ideas about the world wide web much later, in 1989. The HTML and HTTP languages and the URL grammar were born soon afterwards, around 1990-91. 


\section{The Importance of the $1980 \mathrm{~s}$}

So what happened between the 1970s, the times of the ARPANET and its followers, and the 1990s when the internet arrived? The answer is that the period of the $1980 \mathrm{~s}$ was the time of videotex, internet's forerunner.

What role did that type of system and technology play? How can we describe this development, technology, structure, and/or user influence?

Applications had an important role here. Several mail-oriented systems, as well as computer conferencing, emerged at different points of time in the 1970s. Thereafter, interactive services based on those systems spread in the 1980s. Nevertheless, when did user oriented networking really "start"? In addition, were Nordic developers and enthusiasts around, at the time of the "birth"?

There are different types of answers to this. Certain experts tend to stress the importance of the basic technology and network structure, while others refer to the situation of the information providers, and yet a third group take the perspective of the user and analyze types of services.

How did so many technologically inexperienced users suddenly become aware of these new possibilities of contact? How did it eventuate that hundreds of thousands of users started to connect through early mail forms, and that certain large groups began to use numerical addresses like 3615 (in France), to connect to communications, advertising, and telephone type services through new terminal devices, or home or office equipment? This all happened long before the PC.

\section{Characteristics of Videotex Systems}

We cannot completely exclude the comments about technology here, since it influenced network structure. Videotex was a type of communication characterized by a type of transmission, speed, interactivity, and user-screen presentation form. Transmitted on packet switching networks and with coordinated gateway protocols, the message transmission speed of videotex was $1,200 \mathrm{bps}$ in and $75 \mathrm{bps}$ out. The presentation screens contained 24 rows and 40 columns for characters and picture elements.

At the approach of the 1980s, the challenge regarding the character representation language for videotex in Europe stood between the UK - with its Viewdata system, renamed Prestel, and France - with Teletel and the Minitel terminal (whose production cost was 100 Euro!). France had a clear formal lead; in user numbers, which had increased enormously (in 1984, there were already 1.8 million Minitel users and, in 1993, 6.3 million users). Nevertheless, the cultural differences played a role, and a number of European countries chose Prestel instead of Teletel for their networks.

An attempt to unify the standards based on compatibility problems was tried by the central European telecom organization CEPT, which defined a common videotex standard in the late 1970s. Implementations were introduced at the beginning of the 1980s. An increasing number of countries successively chose the CEPT-3 as standard, since it was flexible and technically efficient. However, several countries had already invested in Prestel and Teletel. 
The Nordic countries that found themselves, individually, with the initial choice of the Prestel standard, later changed to CEPT-3. However, these decisions were mainly unilateral.

Important parts of the struggles concerning the standards were fought based on applications. A number of large companies invested in services that depended on standards and, as it transpired, during the 1980s, the network operators were not strong enough to force the unification of standards. In addition, the global plurality of videotex made cooperation difficult. For example, in the U.S., the NAPLPS standard (North American Presentation Level Protocol Syntax) grew in the 1980s, while in Canada, which was an early videotex enthusiast, the more graphically able Telidon standard was used quite extensively. On the other hand, in Japan, the flexible CAPTAIN could present the Japanese language visually, which Japanese applications naturally needed. This confusion about global standards did not help national cooperation.

The terminals used for videotex came from a line of major equipment producers, including some from Nordic countries. During the latter part of the 1980s, software that made communication in videotex format via PC possible became available for PCs.

In the Scandinavian countries, this network concept for the information market was first called "teledata." The Swedish PTT, Televerket, used the term "Datavision" for a time, but the U.S.-rooted term "videotex" [1] was finally chosen by many in the middle of the 1980s.

\section{Pioneering Work}

From the 1970s and onwards, an important influence emerged in the U.S. regarding services that early emphasized message communications. Public mail and computer conferencing appeared before 1970 [2]. Jaques Valle and Bob Johansen at the Institute for the Future, in Menlo Park, were also among the early creators of new social contact systems.

With regard to the Nordic development, mentioning these pioneers is relevant. Turoff and Hiltz were visitors and discussion partners not only in Sweden (on several occasions from the middle of the 1970s), but also in Vallee. In particular, Johansen visited Sweden on numerous occasions until the end of the 1980s, discussing and implementing project ideas. These pioneers were influential and in 1977, Bertil Thorngren and Tomas Ohlin implemented public mail applications in the north of Sweden [3]. In addition, Jacob Palme developed his important KOM system in 1978, after inspiration from Turoff and Hiltz [4].

However, for Europe in general, France defined a user market, although, in all honesty, France received its inspiration from the United Kingdom. Around 1970, Sam Fedida at the British Post Office experimented with a connection between the telephone and the television. The issue was expanding and finding new applications for the telephone network. His invention, called "viewdata," allowed the user to "see the text." Fedida aimed at the home user, whose telephone usage at the time was low.

Ceefax complemented viewdata in the UK, which was a TV bound one-way teletext service that used a few upper lines of the TV picture for centrally produced text and comments. This was followed in numerous countries, as centralized TV bound short text services were evident and understandable. 
At the same time, French experiments were being carried out [5]. In 1970, services for numerical calculations via the telephone were presented in Issy-les-Moulineaux. Issy continued to be early with its creative appetite. Later in 1972, the French telecom research institute CCETT was established, in order to bring together telephony and TV research. At the SICOB fair the same year, flexible message output was shown, both in synthetically vocal form and visually. In Vélizy, a practical demonstration of a screen presentation was attempted. Telecommunications analysis expanded and, in 1975, the French X.25 bound Transpac data network was presented.

In 1975, much to the surprise of the French developers, they discovered that the UK intended to start a Viewdata service very soon. The French were hurt. In 1976, President Valéry Giscard d'Estaing asked Simon Nora to produce a visionary report about the information society. This work, by Simon Nora and Alain Minc [6], would become important for the expansion of applications and for user understanding of public network services. With support from the French government, it helped pave the way for Minitel and for its successors also internationally. There were other visionary reports at that time (such as the "Instant world" report, produced by the Canadian government, work led by Douglas Parkhill, Canadian Ministry of Communications), but they were not many.

These descriptions of the information society made it apparent that both the private and the public sector would be interested in new types of communications. Contributions indicated that the citizen as well as the consumer was interested. Applications and services of a democratic nature started to appear; questions were raised about the possibilities of electronic voting.

Pioneers such as Yoneiji Masuda in Tokyo, defined a space where thoughts about cooperation could be expressed on public platforms. Masuda visited Sweden on several occasions at the end of the 1970s, and even discussed Nordic public applications, in his monumental book "Information Society" [7]. He proposed a democratic arena that provided citizen access on the new online platforms.

\section{Early Videotex Networks}

At the beginning of the 1980s, a number of different national videotex networks were created, several of them conceptually inspired by the French system. Packet switching technology was used for the supporting structures.

The influence of the French videotex system had certain characteristics:

o a decentralized system structure allowed local hosts to be connected everywhere in the network,

o flexible payment was centralized, combined with telephone bills,

○ public e-mail was introduced,

- Annuaire Electronique, a centralized telephone book, was provided online in France.

These characteristics of the pioneering French systems were not introduced in the videotex systems of all other countries, but they played important roles in these countries' national expansion. Table 1 lists which standard was utilized and the year of the official launch of videotex services (trials were conducted earlier) in European countries. 
Table 1. Launch of videotext

\begin{tabular}{ccc}
\hline Country & Launch & Standard \\
\hline Austria & 1984 & Prestel \\
\hline Belgium & 1986 & Prestel \\
\hline Denmark & 1985 & Prestel / CEPT-3 \\
\hline Finland & 1986 & Prestel \\
\hline France & 1984 & Teletel \\
\hline Germany & 1984 & CEPT-3 \\
\hline Italy & 1985 & CEPT-3 / Prestel \\
\hline Netherlands & 1984 & Prestel \\
\hline Norway & 1986 & Prestel / CEPT-3 \\
\hline Sweden & 1982 & Prestel (CEPT-3 in 1987) \\
\hline Switzerland & 1986 & CEPT-3 \\
\hline UK & 1980 & Prestel
\end{tabular}

\section{The Nordic Connection}

In several countries, there were groups of enthusiasts who recognized what was happening. Widespread interactivity attracted attention, creating interest and tension. Established technological market forces took a stand, usually restrictive at the beginning. Furthermore, several representatives of the existing telecom networks and industries considered the initially small islands of videotex users as competitors.

Finland was an early videotex country. Inspired by the French development and through early personal contacts, they began to conduct experiments in Helsinki at the beginning of the 1980s. The leading newspaper, Helsingin Sanomat, was active, together with the inspired developer Jaako Hanukselä. An analysis was made concerning online news and experiments were carried out locally and shown at Nordic conferences. Other early producers of Finnish information included the business chain SOK.

In Denmark, the Danish PTT was conducting videotex trials, called Teledata, from 1980 onwards; the official market introduction occurred in 1985. Norway conducted Teledata field trials already from 1979 onwards, with the commercial launch in 1986.

In the middle of the 1980s, a number of types of service applications, including grocery sales, travel reservation, and insurance and banking services were tried in almost all Nordic countries.

In some, a politically based public analysis was initiated. One of the forces behind this was the mass media, but after the first shock, newspapers and TV became nervous. Was this a serious threat to the ordinary paper bound press?

In Sweden, a parliamentary commission, Informationsteknologiutredningen [8], including leading politicians, was formed in 1978. Its secretary was Tomas Ohlin. The newspapers had been actively supporting the creation of this commission; they were concerned about the possible competition from electronic information forms. The results of the commission's analysis were rather broad, it was noted that this media change would take time. Actually, the regulation of commercial online information (advertisements) was politically proposed, but never implemented. Similar commissions or public analysis groups were created in other countries. 
The late 1970s and the beginning of the 1980s were times of analysis. Existing market forces had to become involved.

\section{User Influence}

In several countries in the 1980s, information providers formed branch-oriented organizations. For example, in Sweden, Videotexföreningen was formed in 1983, and later expanded into InformationsProducentFöreningen, IPF (with active chairman Tomas Persson). Internationally, the Association for Videotex Information Providers already existed. The driving market forces behind the development of Swedish videotex were Aktievisionen (financial services, developed by Paul Östling), LantbruksData (services for farmers), ATG (administrative services for gambling), TINA (Teledata I Norr, with regional services), and Riksdagen (public information services), as well as banks and insurance companies.

Videotexföreningen developed ethical guidelines for videotex already in 1985 [9]. These were among the first such guidelines published globally.

A group of Swedish industrialists created the company TeleGuide in 1988. The organizations behind this company were IBM, Esselte, and Swedish PTT Televerket. The aim of Teleguide was to repeat the French success with Minitel, for home applications.

Plans were to develop further the Swedish PTT videotex network. A dedicated terminal equipped with a smart card reader, aimed at the electronics market, was bought from Loewe in Germany. In 1990, they advertised the following TeleGuide services:
○ Telephone address book
○ Banking
O E-mail
○ Postal services
- Public debates
○ Online market
○ Postal services
- Financial services
o Public information
o Mass media information
o Travel
○ Insurance
○ Information retrieval
o Games

Several of these services were in early forms of development, but the marketing was offensive.

Due to a lack of collective financial support, plans for joint Nordic activity were drawn up but not implemented. The TeleGuide company did not receive any public support and was only able to attract 22,000 customers. The PTT interest decreased over time and, after three years, the project was discontinued. It had been too early; there was no market for its services.

\section{The PTT Positions}

The activities of the PTTs [10] were offensive at the beginning; telephone based profits were still substantial. However, conceptually, the plans were conservative, from user perspectives. The old single market thinking ruled. PTTs employed many 
engineers, who at times had a limited understanding of small-scale online market services for the office and home.

There were, however, certain markets that were offensive at an early stage, often based on powerful organizations such as farmers' services, medical drug markets, banks, and insurance companies. In order to service these markets, the PTTs kept the X.25 network and its videotex counterpart network, in good shape technically. Nevertheless, not everyone was quite willing to accept new market thinking, smallscale usage as well as strong competition.

After a thorough analysis, the Swedish PTT videotex network was discontinued in 1992-93. Although the internet was not fully available at the time, there was an expectant feeling among experts that the different videotex networks would have difficulty cooperating well. Compatibility problems among network dialogues were substantial.

In addition, information providers were dissatisfied with the, in essence, monopolistic PTT. Opposition was evident with regard to the making of certain policies. Reasons for closing the Swedish PTT videotex network were:

○ Videotex was a cultural problem for PTT

- Telecom markets were beginning to be liberalized, no monopolies

- Resources were scarce, with no state support

- The videotex network (CEPT type) was expensive

○ The number of users was too small

- TeleGuide was closed

- The compatibility problems between networks were too costly

○ New types of equipment appeared, teletex, ISDN, smart phones

\section{Problems for the Small Network Islands}

At the beginning of the 1990s, national videotex networks were becoming aware of problems. The market was not expanding to expectations; new technology (new terminal types, and the PC) and new system structures were appearing. It transpired that the problems that had become relevant for the Swedish PTT had also become relevant for others. In this respect, there were Nordic contacts.

However, French Minitel had shown what later was to become an internet market. The Teletel network that formed the base for the Minitel success (reaching over seven million terminals) was created according to certain principles of decentralized system structure, centralized payment, a "killer app" (phonebook), plus e-mail.

In many countries, there were attempts to duplicate this, for example, the Swedish TeleGuide. This system failed because the application development policy was too narrow, financial support was lacking, as was, subsequently, customer interest.

\section{Transition from Videotex into the Internet}

No doubt, there were a number of advantages with the videotex format such as low cost, ease of use, flexibility, and interactivity. There were also disadvantages such as slow speed and a lack of graphical sophistication 
For a medium of its time, these characteristics were important and no doubt showed the way for the internet. Videotex was a fantastic medium because it was so early with direct user interactivity and influence. Several of internet's later successful services stem from videotex developments in the 1980s.

Historically, it is certainly not the first time that small decentralized services, after initial development problems, pave the way for a broader, centrally combined and successful system. In the early 1990s, many observers had noted Minitel and the different videotex islands, and they had been increasingly convinced that this was a development on which to expand.

In this author's opinion, there is no doubt that the internet would have taken much longer to arrive were it not for the experiences gained from the regional videotex systems. The concepts of the electronic market and the open platforms were already established when the internet arrived.

Videotex had an obvious educational effect on the coming online market. It was the first widely distributed system, which enabled users to become acquainted with controlled interactivity, with early public access, thus becoming a pioneer system for democratic dialogue.

It is often important to be at the right place at the right time. Successful inventions have historically arrived at a time when there is sufficient user understanding. The invention of a technical standard and a network grammar is a beautiful achievement. However, large groups of users form the basis for the real gold medals.

Strangely enough, in 2010 there are still a number of Minitel terminals in France. Phonebook services and personal mail are, to some extent, still used with this equipment, although such use must surely be declining. It is amazing, however, that a network invention from the 1970s can survive for over thirty years in these times of explosively rapid technological development. Videotex paved the way for the internet, and platforms for the many, although there is a lesson in that social platforms need time to mature.

\section{Conclusion}

If not for videotext, the internet would have arrived on the international (including the Nordic) user market several years later than its actual introduction. Some reasons for this relate to user maturity. Videotex enabled millions of new network users to gain an understanding of the new system. Although not an earthquake in the technical sense, its speed and standardization was only low. It was, however, a system that introduced user interactivity, which was a substantial contribution to network expansion. Suddenly, users found themselves with influence.

What can we say about Nordic contributions? Although the Scandinavian countries were early, they were not at the forefront. However, they did provide important test markets for the coming videotex systems. Actually, during discussions with Frank Burgess, general manager of Prestel in the middle of the 1980s, he confirmed quite clearly that expansion into the Nordic markets had been a necessity for Prestel, and this had provided training for other market developments. Burgess visited the Nordic countries frequently and was keen to maintain close contact with Scandinavian representatives. 
This is also relevant for the introduction of CEPT-3. There was close contact between the Nordic countries and CEPT representatives in the middle of the 1980s. The Scandinavian countries were important start-up markets that were used to test several aspects, both technically and with regard to new applications. The Nordic countries were important partners for the expansion of videotex and they helped pave the way for the internet, about ten years later.

\section{References}

1. Ohlin, T.: Videotex. Riksdataförbundet, Stockholm (1986) (available via Tomas Ohlin)

2. Hiltz, S.R., Turoff, M.: The Network Nation. New Jersey (1978)

3. Ohlin, T., Thorngren, B.: Projekt TERESE. Styrelsen för Teknisk Utveckling, Stockholm (1976-1977)

4. Palme, J.: History of the KOM Computer Conferencing System (1978), http://people.dsv.su.se/ jpalme/s1/history-of-KoM.html

5. Abadie M.: Minitel Story. P. M: Favre Publi S.A., Paris (1988)

6. Nora, S., Minc A.: Linformatisation de la societé. Paris (1977-1978)

7. Masuda, Y.: Information Society, Tokyo (1976)

8. SOU 1981:45. Informationsteknologiutredningen. Stockholm (1981)

9. Ohlin, T., Synnerstad, K.: Etiska riktlinjer för videotex. Videotexföreningen (1985)

10. Lernevall, S., Åkesson, B.: 11.8 Videotex. In: Svenska Televerket, Del VII, Från myndighet till bolag 1966-1993. Televerket: Telia, Norstedts förlag, Stockholm (1997) 